\title{
Forty lives in the bebop business: mental health in a group of eminent jazz musicians ${ }^{\dagger}$
}

\author{
GEOFFREY I. WILLS
}

\begin{abstract}
Background Above-average levels of psychopathology have been

demonstrated convincingly in groups of outstanding individuals working in the arts. Currently, jazz musicians have not been studied in this regard.
\end{abstract}

Aims To investigate any evidence of psychopathology in a group of eminent jazz musicians.

Method Biographical material relating to 40 eminent American modern jazz musicians was reviewed and an attempt was made to formulate diagnoses using DSM-IV.

\section{Results Evidence was provided of} levels of psychopathology in the sample of jazz musicians similar to those found in other previously investigated creative groups, with the exception of substancerelated problems. An interesting connection between creativity and sensation-seeking was highlighted.

\section{Conclusions The link between} psychopathology and creativity in the arts was given further weight. Future studies of jazz musicians using larger samples and making comparison with groups from different eras of music would give greater clarification to this area.

Declaration of interest None.
There is now a comprehensive literature that convincingly demonstrates a link between psychopathology and creativity in the arts. Specifically, the work of Andreason (1987), Jamison (1993), Post (1994) and Ludwig (1995) points to a connection between creativity and affective disorders, but there is also evidence of other psychopathology. As just one example of this, Post (1994) found that $40.4 \%$ of his sample of eminent composers exhibited DSM cluster $\mathrm{C}$ (anxious type) personality disorder traits.

Jamison, Post and Ludwig studied biographies of eminent creative persons in order to carry out their assessments. In the largest of these studies, Ludwig (1995) gathered biographical data on 1004 famous men and women and concluded:

'My findings show consistently that members of the artistic professions or creative arts as a whole... suffer from more types of mental difficulties and do so over longer periods of their lives than members of the other professions.

Eysenck (1995), in his overview of creativity, felt that a number of studies supported the theory that:

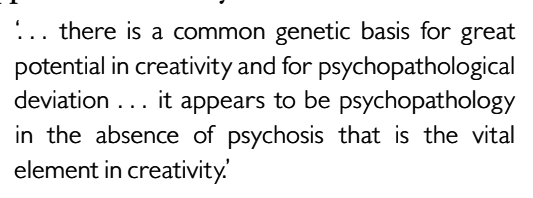

A recent book by Nettle (2001) explores these themes further.

Between them, the workers mentioned above have studied psychopathology in fine artists, architects, classical musicians (composers and performers), entertainers, actors, playwrights and writers of fiction and poetry. One area of creative endeavour that has been given scant attention is jazz, even though Jamison (1993) mentioned three jazz musicians in her study and Ludwig (1995) included seven in his. This is unfortunate because, as DeVeaux (1997) says:

$\therefore$. there is little doubt that in recent years it (jazz) has made substantive leaps toward becoming "America's classical music" . . . it may well be . . . that jazz is in the same position as another vernacular art form, film, was a generation ago: on the verge of becoming absorbed into official academic culture.'

And Shipton (2001) states, quite simply, that ' $O f$ all the musical forms to emerge in the twentieth century, jazz was by far the most significant'. In order to increase the comprehensiveness of the study of artistic creative persons, therefore, it seems timely to focus on jazz musicians.

\section{Present study}

In the present study I have not been as ambitious as Jamison, Post and Ludwig in terms of the size of the sample. I have targeted a particular period of jazz, which it is possible to refer to as the classic era of American modern jazz, that lasted from about 1945 to about 1960. Bebop, the first manifestation of modern jazz, 'Lies at the midpoint of what has become known as the jazz tradition ... bebop is the point at which our contemporary ideas of jazz come into focus' (DeVeaux, 1997). By the early 1960 s, the music was changing again, largely as a result of what was known as The New Thing, The New Wave, or Free Jazz. In targeting a particular era of jazz, I am nevertheless mindful of the words of Harrison et al (2000) when they say that 'In reality, the parameters according to which periods are demarcated are so manifold and overlapping that valid periodization may be almost impossible to achieve'. Still, the period 1945-1960 gave prominence to a large group of innovative and virtuosic jazz musicians who form a convenient and compelling group for study. Jazz musicians from other eras will form comparison groups who may or may not reveal similar personal characteristics.

\section{METHOD}

\section{Sampling}

Forty jazz musicians who are regarded generally as having emerged as innovators on their instrument and often regarded in other ways, for instance as composers or arrangers, in the period 1945-1960 were selected using the standard jazz texts The Encyclopaedia of Jazz (Giants of Jazz section) (Feather, 1960), Jazz Masters of the Forties (Gitler, 1966) and Jazz Masters of the Fifties (Goldberg, 1965). Twenty-six $(65 \%)$ of the musicians were African American and 14 (35\%) were Caucasian American. All were born in the period 1912-1936 and all were deceased. The sample (Table 1) consisted of six 
trumpeters, three trombonists, four alto saxophonists, one alto doubling tenor saxophonist, five tenor saxophonists, three baritone saxophonists, five pianists, five bassists, four drummers, one guitarist, one vibraphonist and two arrangers.

Following the approach of previous researchers, biographical material was reviewed. Twenty-two musicians had biographies devoted to them, in some cases more than one. Where biographies per se did not exist, whole chapters devoted to individual musicians in jazz histories and reference works were referred to, supplemented by jazz magazine interviews and articles, providing extensive information on personality, health and other details.

\section{Ratings}

Where possible, I attempted to transform the biographical data into psychiatric diagnoses by using classifications and criteria from DSM-IV (American Psychiatric Association, 1994). The categories used were: heroin-related disorder, alcohol-related disorder, cocaine-related disorder, schizophrenia and other psychotic disorders, mood disorders and anxiety disorders. The categories of family background, sensation-seeking, late-life deteriorations and suicides also were added. Although the use of cannabis by jazz musicians has been a topic for discussion (e.g. Shapiro, 1988), the category of cannabis-related disorder was omitted owing to a lack of information in the biographical material.

\section{RESULTS}

\section{Family background}

Information on family psychiatric history was rather patchy. It was ascertained that four subjects (i.e. $10 \%$ of the sample) had problems in this regard: Art Pepper's parents, Stan Getz's maternal uncles and Bill Evans's father had alcohol-related disorders, whereas Stan Getz's mother had depression and Bill Evans's brother died by suicide. Erroll Garner's twin brother had severe learning difficulties. Seven subjects $(17.5 \%)$ experienced an unhappy or unstable early life: for instance, Dizzy Gillespie and Charles Mingus remembered being beaten by their father, and Charlie Parker's father deserted the family when Parker was 10 years old. Miles Davis had an acrimonious relationship with his mother, who whipped him when he was young. On the other hand, he was one of five subjects $(12.5 \%)$ who came from well-to-do or middle-class backgrounds. Davis's father was a wealthy dentist and ranch owner. Serge Chaloff's father was a symphony orchestra pianist and his mother was a music conservatory teacher.

Table I Forty eminent modern jazz musicians and their instruments

\begin{tabular}{lll}
\hline Trumpet & Trombone & Alto saxophone \\
Dizzy Gillespie & J.J. Johnson & Charlie Parker \\
Fats Navarro & Frank Rosolino & Art Pepper \\
Clifford Brown & Bill Harris & Paul Desmond \\
Chet Baker & & Eric Dolphy \\
Miles Davis & & Alto/tenor saxophone \\
Howard McGhee & & Sonny Stitt \\
Tenor saxophone & Baritone saxophone & Piano \\
Wardell Gray & Serge Chaloff & Bud Powell \\
Dexter Gordon & Gerry Mulligan & Thelonious Monk \\
Stan Getz & Pepper Adams & Erroll Garner \\
Hank Mobley & & Lennie Tristano \\
John Coltrane & & Bill Evans \\
Bass & Drums & Guitar \\
Ray Brown & Kenny Clarke & Charlie Christian \\
Oscar Pettiford & Art Blakey & Vibraphone \\
Charles Mingus & Philly Joe Jones & Milt Jackson \\
Paul Chambers & Shelly Manne & Arranger \\
Scott La Faro & & John Lewis \\
& & Gil Evans \\
\hline & & \\
\hline
\end{tabular}

\section{Heroin-related disorder}

Twenty-one subjects ( $52.5 \%$ of the sample) were addicted to heroin at some time during their lives. It must be noted that heroin use was widespread among modern jazz musicians in the period after the Second World War and there were a number of reasons for this. After the war there was a dramatic increase in the availability of heroin because supply routes from the Far East and Turkey were re-opened by the Mafia. Heroin travelled via Marseilles directly to New York and was made easily accessible (Shapiro, 1988). It 'flooded urban black neighbourhoods to plague the lives of average working-class AfricanAmericans' (DeVeaux, 1997). Modern jazz was a revolutionary music that was rejected by the general public, and heroin, like the music, was defiantly anti-establishment (Hentoff, 1978). It thus tended to be adopted by disaffected musicians.

Heroin addiction was felt to be a contributing factor to early death in five of the subjects. A further subject, Chet Baker, lived until the age of 58 years but remained a lifelong addict. Fourteen subjects overcame their addiction but five relied on other substances, such as alcohol, cocaine and methadone, to sustain them.

\section{Alcohol-related disorder}

Eleven subjects $(27.5 \%)$ were dependent on alcohol and six (15\%) abused alcohol at some stage during their lives. Eleven subjects $(27.5 \%)$ were comorbid for other disorders, such as heroin and/or cocaine dependence at certain times in their lives. Five of the alcohol-dependent subjects eventually overcame their dependence.

\section{Cocaine-related disorder}

Three musicians (Miles Davis, Art Pepper and Bill Evans) developed a dependence on cocaine. In each case it followed the cessation of heroin use. In the case of Bill Evans, there was a 10-year abstinence before the commencement of cocaine use. Other musicians known to use cocaine were Thelonious Monk and Chet Baker.

\section{Schizophrenia and other psychotic disorders}

Three subjects $(7.5 \%)$ had psychotic disorders. 


\section{Schizophrenio}

Bud Powell had numerous admissions to psychiatric hospitals and was diagnosed as having schizophrenia. Many musician colleagues believed that his illness was triggered after he was beaten over the head by police when he was 21 years old. Although he exhibited schizophrenia-like symptoms such as possible paranoid delusions (fear of being attacked and murdered), possible auditory hallucinations (laughing inappropriately to himself) and inappropriate affect (fatuous smile, grimace, fixed stare), throughout a 10-month hospital admission in 1945 it was reported that 'he talked garrulously to all who would listen and was generally over-active... his thoughts were flying away with him' (Gitler, 1966) and, therefore, a more accurate diagnosis may be one of schizoaffective disorder, because schizophrenia was grossly overdiagnosed and mania was underdiagnosed around the middle of the 20th century. To complicate the picture further, one medical researcher suggested that Powell might have developed epilepsy as a result of his beating. These issues will not be resolved fully until the Powell estate releases the medical records.

\section{Substance intoxication delirium}

Thelonious Monk experimented freely with a variety of drugs and appeared to experience a particularly adverse reaction to amphetamines. There were regular episodes when he went without sleep for several days, pacing up and down and not appearing to recognise anyone. After taking to his bed for a few days he would then return to normal. This presentation conforms to a diagnosis of substance intoxication delirium, as described in DSM-IV.

\section{Substance-induced psychotic disorder}

Miles Davis developed sickle-cell anaemia and used excessive amounts of cocaine and barbiturates to control the arthritic pain. As a result, he developed paranoid delusions and auditory hallucinations, searching in his house for imaginary people whose voices he thought he heard.

\section{Mood disorders}

Eleven subjects $(28.5 \%)$ definitely or probably fell into this category (Table 2). Four subjects received in-patient treatment for a depressive disorder and one subject, Frank
Rosolino, although not diagnosed as having depression, died by suicide after attempting (successfully, in one case) to kill his two sons.

\section{Mood disorder due to a general medical condition}

Two subjects fell into this category: Miles Davis had depression as a result of pain caused by sickle-cell anaemia, whereas Gerry Mulligan experienced mood swings caused by hypoglycaemia.

\section{Dysthymic disorder}

Two subjects, Paul Desmond and Bill Evans, appeared to have dysthymic disorder. Both experienced low self-esteem, guilty ruminations and a pessimistic outlook. In the case of Desmond, dysthymia was related to alcohol dependence, whereas with Evans it was related to heroin dependence.

\section{Cyclothymic disorder}

Charles Mingus displayed symptoms of a cyclothymic mood disorder, being mainly hypomanic with irascible, paranoid and grandiose features. Oscar Pettiford presented a similar picture, being irascible, grandiose and unrealistic in his business dealings. When alcohol-free, he was reported as appearing depressed.

\section{Anxiety disorders}

Two subjects (5\%), Art Pepper and John Coltrane, appeared to have anxiety disorders. Art Pepper carried out obsessivecompulsive washing rituals and had phobic anxiety regarding the sight of blood, hospital operations and answering the telephone. John Coltrane exhibited obsessivecompulsive features related to excessive practising, consumption of sweet foods, dieting, searching for the perfect mouthpiece and constantly exploring various religions. In relation to Coltrane, it is interesting to note that obsessionality can have an adaptive function in creativity, and Storr (1972) discusses the use of ritual to induce a suitable state of mind.

\section{Sensation-seeking}

Zuckerman (1994) has described sensationseeking as 'the tendency to seek novel, varied, complex, and intense sensations and experiences and the willingness to take risks for the sake of such experience'. It 'seems to be a necessary but not sufficient ingredient of an antisocial personality' (Zuckerman, 1994) and has been linked to borderline personality disorder (Reist et al, 1990). It seems possible, therefore, that sensation-seeking is a characteristic of all DSM cluster B (dramatic type) personality disorders. Sensation-seeking also has been linked to creativity, in the form of divergent thinking (McCrae, 1987), and to a preference for complexity and abstraction in art (Furnham \& Bunyan, 1988).

In terms of the sample as a whole being rated as exceptionally creative, I felt that it would be interesting to look at the documentation of sensation-seeking tendencies in biographical material.

\section{Disinhibition}

One of the sensation-seeking factors identified by Zuckerman (1994) is disinhibition.

Table 2 Mood disorders

\begin{tabular}{ll}
\hline Musicians & Diagnosis \\
\hline Miles Davis & Mood disorder due to sickle-cell anaemia, with depressive features \\
Paul Desmond & Dysthymic disorder \\
Bill Evans & Dysthymic disorder \\
Gil Evans & Major depressive episode \\
Stan Getz & Major depressive disorder, recurrent' \\
Charles Mingus & Major depressive disorder, recurrent, superimposed on cyclothymic disorder' \\
Gerry Mulligan & Mood disorder due to hypoglycaemia with mixed features \\
Charlie Parker & Major depressive episode' \\
Art Pepper & Substance-induced mood disorder with depressive features' \\
Oscar Pettiford & Cyclothymic disorder (?) \\
Frank Rosolino & Major depressive episode (?) \\
\hline
\end{tabular}

I. In-patient hospital treatment. 
This is typified by a liking for parties, social drinking, sex with many partners, new and often illegal experiences and experimentation with drugs. Five of the subjects $(12.5 \%)$ shared a remarkably similar profile regarding disinhibition. These were Chet Baker, Charlie Parker, Art Pepper, Stan Getz and Serge Chaloff. Chet Baker's favourite drug experience was 'the kind of high that scares other people to death - a speedball. It's a mixture of cocaine and heroin'. Charlie Parker consumed enormous quantities of food, used heroin in increasing amounts, was known to drink 16 double whiskies in a 2-hour period and entered into hundreds of affairs with women. Art Pepper described his appetites thus: 'I always prided myself on being able to stay up longer than anybody else, drink more than anybody else, take more pills, shoot more stuff, or whatever'. Stan Getz was dependent on heroin and alcohol and was a prolific womaniser. Serge Chaloff was described by a colleague as being like Charlie Parker: 'He had such an amazing tolerance for doing whatever he did to himself that he hardly ever knew it was a problem... never got enough of anything'.

Miles Davis appeared to exhibit extreme disinhibition. He misused a variety of substances, including heroin, alcohol, barbiturates and cocaine. He had many sexual relationships, sometimes simultaneously, and he had a liking for orgies and voyeurism. Other subjects, including Dexter Gordon, Paul Chambers and Philly Joe Jones, demonstrated voracious multiple appetites.

\section{Thrill- and adventure-seeking}

Thrill- and adventure-seeking is another sensation-seeking factor identified by Zuckerman (1994). In the present sample, Chet Baker and Miles Davis had a love of fast sports cars, and Scott La Faro, a notoriously reckless driver, died in a car accident at the age of 25 years. On one occasion after a drinking session, Stan Getz successfully swam across London's River Thames.

\section{Late-life deteriorations and suicides}

It was felt that from the age of 54 years Thelonious Monk had a dementing process caused by excessive drug usage. He died from a cerebral aneurysm, aged 64 years.

At the age of 52 years Frank Rosolino shot his two sons (killing one and seriously wounding the other) and then killed himself. J. J. Johnson, having been ill for a number of months, died by suicide at the age of 77 years.

\section{DISCUSSION}

\section{Shortcomings of the study}

Ludwig (1995) and Post (1994) discuss the shortcomings in their studies and the same criticisms can be levelled at the present one. Information was taken from soft biographical data and interpreted as facts. A single investigator attempting to translate descriptions of subjects in biographies into specific DSM diagnoses cannot achieve high levels of validity and reliability. Biographers may be biased in the way that they select and interpret facts, and information is retrospective. Ideally, the subjects should have been selected from a list provided by a group of experts. The present sample of $\mathbf{4 0}$ subjects is small and rose to prominence in a very specific era that had a strong influence on them as individuals. Nevertheless, objective data were available in the form of documented behaviours, such as medical or psychiatric illnesses. Often there were several biographies of one subject, each written from a different standpoint and providing crosscorroboration of data.

\section{Statistical comparisons with other studies}

It was interesting to compare and contrast rates and types of mental health problems in the sample of jazz musicians with those of previously documented creative groups.

Overall, the statistics for jazz musicians were comparable with those of composers and musical performers provided by Post (1994) and Ludwig (1995). For instance, $28.5 \%$ of jazz musicians had mood disorders compared with $41 \%$ of musical performers (Ludwig) and 34.6\% of composers (Post); and $10 \%$ of Ludwig's and $1 \%$ of Post's composers had a psychotic illness compared with $7.5 \%$ of jazz musicians. Figures for alcohol problems were similar, with $40 \%$ of Ludwig's musical performers, $21.2 \%$ of Post's composers and $27.5 \%$ of jazz musicians. Thus, the present study tended to confirm previous findings regarding mood disorders and alcohol problems in creative persons. Comparable statistics for the general population during the time period studied are not easily available. The Midtown Manhattan Study (Srole et al, 1962) did not determine the presence of specific mental disorders, stating only that $23 \%$ of the sample population had significant psychiatric impairment. The Epidemiologic Catchment Area Study (Robins \& Regier, 1991) found incidences of $6.8 \%$ for mood disorders, $1.5 \%$ for schizophrenia, $14 \%$ for alcohol dependence and misuse and $6 \%$ for drug dependence and misuse.

\section{Drug-related problems}

There was a much higher rate of drugrelated problems in the present sample than in those of Ludwig and Post, with $52.5 \%$ of jazz musicians having heroin addiction at some time during their lives. As has been noted previously, heroin use was widespread for a number of reasons among modern jazz musicians after the Second World War, but as modern jazz gradually became more accepted, and as younger musicians saw the harm caused to their older colleagues, usage began to fall off (Hentoff, 1978), so a more recent sample of jazz musicians undoubtedly would not show the same rate of addiction.

\section{Consideration of occupational stress}

In a previous large-scale study (Wills \& Cooper, 1988), the effects of occupational stress on mental health and substance misuse in popular musicians were explored. Arguably, the fullest picture is provided by using the diathesis-stress model (Meehl, 1962). One may ask why Dizzy Gillespie survived to become an elder statesman but his fellow innovator Charlie Parker died aged 34 years. Research (see Ludwig, 1995) shows that, with regard to psychopathology in the arts, for substantial numbers the predisposition for mental disorder is established long before they launch their careers. There is also a greater tendency in their families for mental illness and they show more problems during childhood and adolescence than members of non-artistic professions.

\section{Wider implications of sensation- seeking}

Despite the social reasons for drug usage, it is interesting to look at it in relation to the topic of sensation-seeking.

Sensation-seeking, mainly in the form of disinhibition and thrill- and adventureseeking, was described in biographical material relating to many of the current 
sample, suggesting that their substancerelated problems were part of the wider spectrum of their appetites and not simply the result of the influence of their working environment.

The connection between sensationseeking and creativity is a topic worthy of further investigation. One may speculate that those high in creativity and sensationseeking may represent a subset of persons who are attracted to becoming performers in the field of popular music as a whole, when one also considers the biographies of a number of eminent deceased rock musicians. One can carry this speculation further, for instance when looking at the bohemian artistic world of fin-de-siècle Paris. Januszczak (2002) refers to the ether addiction of the poet Max Jacob, the absinthe addiction of the playwright Alfred Jarry, the opium smoking of Picasso and the alcoholism of Utrillo, Toulouse-Lautrec and Modigliani. The latter also used hashish and cocaine.

At the present time, of course, the connection is pure conjecture. Solely with regard to jazz musicians, there is a need to study larger samples and to make comparisons with groups from different eras of the music.

\section{Non-pathological sample characteristics}

To maintain a sense of perspective in the present study, it needs to be stated that many of the sample were exemplary, well-balanced human beings. For instance, Clifford Brown was regarded universally as being kind, generous, conscientious and highly intelligent. Eric Dolphy was known to be gentle, unassuming, helpful and considerate. John Coltrane, Thelonious Monk and Erroll Garner generally were liked very well. Pepper Adams was an exceptionally cultured person who was interested in art history and literature, and his friends regarded him as an excellent museum guide. Many musicians, such as Miles Davis, Art Blakey and J. J. Johnson, overcame early problems to become very successful and highly respected elder statesmen of jazz.

This study offers a further perspective on the link between psychopathology and creativity in the arts, and adds weight to the finding that outstanding workers in the arts can suffer from above-average levels of mental health problems but manage to produce exceptional work

\section{CLINICAL IMPLICATIONS}

- Evidence of a link between psychopathology and creativity in the arts is given further support.

- Further illumination of the creative process might be gained by an intensified study of its link with sensation-seeking.

- Psychopathology is neither necessary nor sufficient for creativity.

\section{LIMITATIONS}

- Information was taken from soft biographical data and interpreted as fact.

A single investigator attempting to translate descriptions in biographies into specific DSM diagnoses cannot achieve high levels of validity and reliability.

- The present sample of $\mathbf{4 0}$ subjects is small and rose to prominence in a very specific era that had a strong influence on them as individuals.

GEOFFREY I.WILLS, PhD, 13 Mile End Lane, Davenport, Stockport, Cheshire SK2 6BN, UK. E-mail: gwils@btopenworld.com

(First received 30 October 2002, final revision 26 February 2003, accepted 17 March 2003)

despite this. Connections with sensationseeking are highlighted, suggesting an avenue for further exploration.

\section{REFERENCES}

American Psychiatric Association (1994) Diagnostic and Statistical Manual of Mental Disorders (4th edn) (DSM-IV). Washington, DC: APA.

Andreason, N. C. (1987) Creativity and mental illness: prevalence rates in writers and their first-degree relatives. American Journal of Psychiatry, 144, 1288-1296.

DeVeaux, S. (1997) The Birth of Bebop: A Social and Musical History. London: Picador.

Eysenck, H. J. (1995) Genius: The Natural History of Creativity. Cambridge: Cambridge University Press.

Feather, L. (1960) The Encyclopaedia of Jazz. New York Horizon Press.

Furnham, A. F. \& Bunyan, M. (1988) Personality and art preferences. European Journal of Personality, 2, 67-74.

Gitler, I. (1966) Jazz Masters of the Forties. New York: Macmillan.

Goldberg, J. (1965) Jazz Masters of the Fifties. New York: Macmillan.

Harrison, M., Thacker, E. \& Nicholson, S. (2000) The Essential Jazz Records, Volume 2. London: Mansell.

Hentoff, N. (1978) The Jazz Life. New York: Da Capo.

Jamison, K. R. (1993) Touched With Fire: Manic Depressive Illness and the Artistic Temperament. New York: The Free Press.

Januszczak, W. (2002) French undressing. Sunday Times Magazine (London), 13 Jan., 18-23.
Ludwig, A. M. (1995) The Price of Greatness: Resolving the Creativity and Madness Controversy. New York: Guilford Press.

McCrae, R. R. (1987) Creativity, divergent thinking and openness to experience. Journal of Personality and Social Psychology, 52, 1258-1265.

Meehl, P. E. (1962) Schizotaxia, schizotypy, schizophrenia. American Psychologist, 17, 827-838.

Nettle, D. (200I) Strong Imagination: Madness, Creativity and Human Nature. Oxford: Oxford University Press.

Post, F. (1994) Creativity and psychopathology: a study of 291 world-famous men. British Journal of Psychiatry, 165, 22-34.

Reist, C., Haier, R. J., DeMet, E., et al (1990) Platelet MAO activity in personality disorders and normal controls. Psychiatry Research, 30, 221-227.

Robins, L. N. \& Regier, D. A. (eds) (1991) Psychiatric Disorders in America: The Epidemiologic Catchment Area Study. New York: The Free Press.

Shapiro, H. (1988) Waiting for the Man: the Story of Drugs and Popular Music. London: Quartet.

Shipton, A. (200I) A New History of Jazz. London: Continuum.

Srole, L., Langer, T. S., Michael, S. T., et al (1962) Mental Health in the Metropolis: the Midtown Manhattan Study. New York: McGraw-Hill.

Storr, A. (1972) The Dynamics of Creation. London: Secker \& Warburg.

Wills, G. \& Cooper, C. L. (1988) Pressure Sensitive: Popular Musicians under Stress. London: Sage.

Zuckerman, M. (1994) Behavioural Expressions and Biosocial Bases of Sensation Seeking. Cambridge: Cambridge University Press. 